\title{
The instructional power of game-based learning and simulation in a K-12 school in the Tehran, Iran
}

\author{
Morteza Alibakhshi Kenari \\ Martyr Beheshti University of Medical Sciences and Health Services, Tehran, Iran
}

Email address:

Morteza.Alibakhshikenari@gmail.com

To cite this article:

Morteza Alibakhshi Kenari. The Instructional Power of Game-Based Learning and Simulation in a K-12 School in the Tehran, Iran. International Journal of Elementary Education. Vol. 3, No. 3, 2014, pp. 86-91. doi: 10.11648/j.ijeedu.20140303.16

\begin{abstract}
Psychologists have often emphasised the need to incorporate games into the school curriculum as a way of providing with learners opportunities to develop in all aspects of the curriculum. Accordingly, these games offer learners an avenue to release their mental tension resulting from rigorous academic engagement. Previous studies have also indicated that the learning process can be made more enjoyable for learners, when games are incorporated into the learning process. This study examined the instructional power of game-based learning and simulation in a K-12 setting and sought to provide insight as to whether game-based learning would be an emphatic method that could be used for teaching and learning. Many scholars have argued that game-based learning stirs up a sense of motivation on the side of learners regarding their learning process. Therefore, this study explored the distinct features of game-based learning which learners consider to be interesting / absorbing. The findings of this study showed that the use of game-based learning as an instruction method is very effective in the teaching and learning process. It has the ability to engage and provoke learners' interests. Besides, its experimental nature allows learners to participate fully in the class work. This means that teachers need to design teaching content that incorporates games since the latter provide a practical learning approach which helps learners to memorize most of the content learn. The study also recommends that educators tasked with designing and developing the curriculum should emphasize the importance of instructional methods that allow teachers to incorporate games into the teaching content.
\end{abstract}

Keywords: Instructional, Game-Based, Learning, Simulation, Online, K-12 Education

\section{Introduction}

Psychologists believe that play an important role in the growth and education of intellectual, social and emotional children. Piaget said that children experience when they play, they realize the cause and effect relationship between relationships. In other words, children through a variety of games, many are learning the rules of collective life.So adults should give the role of play in educating children and enabling them to provide creative games. Capabilities and business confidence is through play that children traditional training is achieved (Desmond 2009). As children play, sincerely and freely express their feelings and principles associated with their age, children learn that eventually leads to an understanding of communication. So, the game will not only increase the child's mind and intelligence, but he is often helps to solve your social and emotional problems (Fuligni 2002). Children who have some difficult and reconcile with the rules and regulations. By playing with kids their age should learn to respect the rules. On the other hand, play an instrument to discover talents and abilities of the child (Hardy 2007). Play can indicate at what level the child is under development and is interested in what. Treated with understanding and applying the tools, talents and abilities donation will lead to greater prosperity. Many of the training courses can be found among the children, and even during the Games can be an emotional situation, his feelings, thoughts and motivations innate realized. Therefore, it is very important that coaches play in the lives of children in mind and provide suitable conditions for good game (Miller 2005).With the increasing use of technology in the classroom, many educators are exploring the use of instructional methods that would enhance their teaching and students' learning (Aldrich 2005). Educators acknowledge the fact that pedagogical practices need to embrace the learning opportunities available in the modern learning environment where learning tools such as computers, the internet, graphics, fantasy tools, and so on are available (Almekhlafi 2010). They also acknowledge that learners' learning 
behavior has changed and therefore more learning materials have to be used in the learning process so as to boost their learning motivations and learning experiences (Al-Rawajfth 2010). Consequently, many educators have embraced gamebased learning with the aim of motivating learners in their learning process (Amorim 2011). A number of games have been incorporated in a range of instructional approaches for educational purposes (Amory 2001). Psychologists argue that there is a positive relation between students' learning and having fun (Assar 2010). Fun is regarded as a fundamental determinant of human behavior (Barta 1998). According to Birch, students are delighted in what their educators ask them to do since it allows them to have fun during the learning process (Birch 2009). Game-based learning enables students to learn by practice; hence, they get engaged in the entire learning process (Bonk 2005). Similarly, games reinforce learner motivation (Bonnah 2010). The main reason why games are considered to be motivating is the fact that participants in the game are obliged to source for the relevant information that can enable them meet the challenges presented by the game (Chiong 2010). In addition, some brain researchers have noted that the inclusion of fun in the learning process boosts the memory ability of the students as the contents that they are taught stick for long in their memory (Deaney 2011).

Games are seen to complement the role of the teacher in the classroom; making learning fun and enjoyable (Demiralay 2010). Video and computer games allow students to simulate situations such as experiments, scientific, and historical events for themselves (Elwood 2009). Similarly, they motivate students, who otherwise are weak in some subject areas by allowing them to encounter 'real problem' and devising ways of how to solve it. Besides, the increased use of games in classrooms has contributed to students' development in other aspects of their personal life (Erdoğan 2010). Hence, skills such as patience, discipline, critical thinking skills, problem solving among others, are learned with the use of games (Ghafar 2011). The study therefore sought to determine the effectiveness of gamebased learning in schools, its influence on students' motivation, and other factors of motivation associated with game-based learning (Goos 2008).

\section{Methodology}

In order to achieve the objective of the study, the researchers adopted a mixed methodology by incorporating both qualitative and quantitative research methodology.
Quantitative methodology is relevant for categorizing the observations or variables, examining the variables and generating statistical representations to analyze the observations. Qualitative approach on the other hand helps generate information that applies to the designated case study. We therefore sampled 450 students and teachers and sent them questionnaires to gather quantitative data. The questionnaire items comprised two major categories including the demographic part and the Likert-scale items and closed-ended items seeking to gather views of the respondents on the study topic. The Likert-scale questionnaire contained 10 items and the other part also contained 5 closed ended items.

237 respondents $(52.6 \%)$ of the expected 450 respondents completed the questionnaires. Female respondents were 142 and male respondents were 95. Many respondents were from the age group 40-49 years (43\%, $\mathrm{n}=101)$. This was followed by respondents in the age group $30-39$ years $(24 \%, n=57)$. The third largest age group was $50-59$ years which had 55 respondents $(23 \%)$. The age group under 30 years had the lowest number of respondents $(10 \%, n=24)$. These results were analyzed using SPSS and correlation analysis. At the same time, the researcher sampled 20 students who were engaged in 13 weeks of game-based learning. Each game-based lesson lasted 30 minutes. At the end of the intervention period, the researchers engaged the participants in an interview. The interview questions sought to answer the questions 'why?', 'how?', and 'what?' as regards the subject of the research.

\section{Results}

\subsection{Survey Results}

Respondents were issued with questionnaires in order to give their responses regarding the instructional power of game-based learning and simulations in education. The results showed that the mean for the effectiveness of gamebased learning was 113.20 , with a standard deviation of 14.30. From this computation, it can be deduced that many students and teachers believed that game-based learning is incredibly effective. This is indicated by the high value of the standard deviation. The mean and standard deviation for the other relationships: the influence of game-based learning on motivation; the impacts of game-based learning on students' learning; and other motivating factors connected to game-based learning and instructional power, are also shown in table 3.1 below.

Table 3.1. Summary of descriptive statistics

\begin{tabular}{llc}
\hline Study question & Mean & Standard deviation \\
\hline Effectiveness of game-based learning & 113.20 & 14.30 \\
Influence of game-based learning on motivation & 102.12 & 11.30 \\
Impacts of game-based learning on students' learning & 103.10 & 10.80 \\
Other motivating factors connected to game-based learning and instructional power & 127.20 & 15.30 \\
\hline
\end{tabular}


Inferential statistics were also calculated and the results showed strong correlations between the influence of gamebased learning on motivation and instructional power $(\mathrm{r}=$ $0.598, \mathrm{p}<0.01$ ), other motivating factors connected to game-based learning and instructional power $(\mathrm{r}=0.585, \mathrm{p}$
$<0.01$ ), effectiveness of game-based learning and its instructional power $(\mathrm{r}=0.386, \mathrm{p}<0.01)$, and between impacts of game-based learning and instructional power ( $\mathrm{r}$ $=0.268, \mathrm{p}<0.05)$.

Table 3.2. Summary of the inferential statistics

\begin{tabular}{lll}
\hline Study question & Pearson Correlation & Sig (2-tailed) \\
\hline Effectiveness of game-based learning & 0.273 & $0.044^{*}$ \\
Influence of game-based learning on motivation & 0.598 & $0.000^{* *}$ \\
Impacts of game-based learning on students' learning & 0.268 & $0.042^{*}$ \\
Other motivating factors connected to game-based learning and instructional power & 0.585 & $0.000^{* *}$ \\
\hline
\end{tabular}

Note: $*=\mathrm{p}<0.05, * *=\mathrm{p}<0.01$

\subsection{Interview Results}

The results of the interview also provided some valuable insights. First, a large majority $(n=16)$ of the students who were interviewed responded that they really enjoyed their learning when it was game-based. The students liked the idea of sourcing information on their own as well as corresponding to their peers as they engaged in problem solving situations. However, the remaining four students responded that their learning motivation did not change even with the introduction of game-based learning. They were mainly motivated by the need to attain excellent grades. Two, it was noted that game-based learning was quite engaging especially with respects to aspects of team work, competition between teams, and the feedback received from the instructor. Game-based learning provided an enjoyable ambience to them as it promoted strong social connection among the students. Three, the use of gamebased learning helped the students to gain interest in their learning as it enabled them to search for information by themselves instead of relying mainly on the notes provided by the teachers in the classroom. Besides, it allowed them to actively participate during the learning process. Fourth, factors such as the aims, desires, and goals of the students were found to be the other motivating factors for the students to work hard in their class work.

The results were analyzed using SPSS and correlation analysis. The responses of the students who were interviewed were listed in five main categories as suggested below:

i. Out of 20 students, 16 of them confirmed that they really enjoyed their learning when it was gamebased. The students had a higher affinity of sourcing for their own information in addition to corresponding with their colleagues in order to meet the challenges of their studies. The students alluded to the fact that learning was more enjoyable in game-based learning as compared to the traditional system of learning whereby the teacher just gave out notes. The remaining four students pointed out that their learning motivation did not change even with the introduction of game-based learning. Their main motivation for learning was the ability to attain excellent grades; thus, the introduction of games did not matter at all.

ii. The students appreciated that game-based learning was quite engaging especially with respects to aspects of team work, competition between teams, and the feedback received from the instructor. Game-based learning provided an enjoyable ambience to them as there is a strong social connection among the students. The learning environment is therefore rendered to be free of stress. When the students work as a team amongst themselves, a feeling of social belonging is created.

iii. The use of game-based learning helped the students to gain interest in their learning because of the fact that the students searched for information by themselves instead of just relying on the notes provided by the teachers in classrooms. In addition, the students did not find any lesson to be boring because of the fact that they were actively participating during the lessons. This notion was supported the fact that the results of the study showed that the class attendance was excellent during the 13 weeks of the course.

iv. The students were comfortable with the 30 minutes that were allocated for the game-based learning as it was effective in stimulating their interests. Nevertheless, the 30 minutes was not found to be sufficient enough to affect the motivation of the students with regard to their learning. The main motivation of the students came from the fact that they desired to attain high grades or scores and to have a bright future with regard to their careers.

v. Besides game-based learning acting as a motivating factor the students, other factors such as the aims, desires and the goals of the students were the main motivating factors for the students to work hard in their studies. Some students pointed out to the fact that they worked so hard in their studies so as to attract confidence and recognition from their parents. 


\section{Discussion}

Games can give children confidence, playing kids healthy and helpful way toward shaping personality (Kurlaender 2006). As a result, the child in the future, have a good life and thriving, the game is very indispensable (Perez 2010). Using this method not only new concepts but also the fundamental values of life in the child's mind closes. Naturally, human learns from the experiences of others to further their words. Some things are learned only by personal experience. You must learn the consequences of their actions. Children learn to become a hobby, not a difficult task (Risco 2011). Maybe you do not accept it, but video games have a high concentration of people and have fun at the same time. In addition, children's games that will strengthen the power of speech, memory and complex scientific concepts to teach them (Phinney 2005). Psychologists emphasise the integration of games in the school curriculum as a way of helping students develop in all their faculties (Granič 2009). Besides, games provide students with an avenue to release their mental tension resulting from rigorous academic engagement (Hsu 2010). The research has shown that the learning process can be made more enjoyable by using games as part of the learning activities. They also add value to learning as they encourages conceptualizing imagined phenomenon to real life experiences (Jumani 2011). In addition, when effectively used, games can facilitate learning because they enable students to learn important life skills such as problem solving skills, patience, critical thinking skills and discipline among others (Kaffash 2010). As opposed to traditional learning methods which mainly involve lecture, game-based learning reinforces learning motivation (Kafyulilo 2010). The main reason why games are considered to be motivating is the fact that the participants in the game get the opportunity to source for relevant information that can enable them to meet the challenges presented by the game (Kan 2011). Traditional learning method is very much different from game-based learning due to the fact that students do not have to think or be creative as they are given the necessary figures or facts to comprehend the essential ones (Karal 2009). The practice of teachers using games in class is gaining popularity at a fast rate. This is especially because it is more appealing to each student and it makes learning more enjoyable and memorable (Katyal 2010). The practice is applicable to all subjects and it only requires a little creativity on the part of the teacher to effectively achieve the lesson objective to a high level (Kazu 2011). Teachers who are not well experienced in the use of games in the classroom can now access resources on the internet on the best practice of transferring games to the classroom (Kirkwood 2009). When effectively used, games can facilitate learning because they enable students to learn important life virtues such as problem solving skills, patience, critical thinking skills and discipline among others. Also, they add value to learning as they encourages conceptualising imagined phenomenon to real life experiences (Law 2010). Despite the positive effects that games bring in a learning environment, improper use can have adverse effects on a student (Leach 2008). Effects such as health problems, abnormal behaviours such as aggressiveness and poor time management can result as a result of improper administration of games (Luck 2010).

The use of games has strong educational values since it is a very sufficient resource for improving the standards of learning. Students are encouraged to shape up their time management skills in addition to being focused and attentive to the teachers' instructions. Just like teachers, some students also find it difficult to embrace new change in the learning environment (Malone 2009). Therefore, it is prudent that, when introducing educational technology to the learning environment, a lot of concern should be attributed particularly to the students who have second thoughts concerning change in the learning environment (Maria 2011).

\section{Conclusion}

Proponents of computer-based learning point out that game-based learning carries with it the capacity to revolutionize the mode of learning in institutions. The modern world students feel more motivated to learn than they would have felt when using traditional methods of learning. The main reason why games are considered to be motivating is that the participants in the game are obliged to source for the relevant information that can enable them to meet the challenges presented by the game. Traditional learning method is very much different from game-based learning due to the fact that students do not have to think or be creative as they are given the necessary figures or facts to comprehend the essential ones. The use of games, therefore, has a strong and immediate impact in the learning environment. The increased use of games in the classrooms has contributed to students' development in other aspects of their personal life. Hence, skills such as patience, discipline, critical thinking skills, problem solving among others, are learned with the use of games. In the future, researchers should look into the various aspects of game-based learning that offer motivation to the students. In addition, the researchers need to come up with the various measures of learning gains and also the degrees of learning. Finally, future studies should explore the effectiveness of game-based learning amongst mentally challenged students. Remember, children should learn many things in life and can play an important role to play in this regard.

\section{References}

[1] Aldrich, C 2005, Learning by Doing: A Comprehensive Guide to Simulations, Computer Games, and Pedagogy in eLearning and Other Educational Experiences. Pfeiffer: San Fransisco, CA. 
[2] Almekhlafi, A and Almeqdadi, F 2010, 'Teachers' perceptions of technology integration in the United Arab Emirates school classrooms', Journal of Educational Technology and Society, vol. 13, no. 1, pp. 165-175.

[3] Al-Rawajfth, K, Soon, F and Idros, S 2010, 'Stages of concern in integrating E-learning in discovery schools' Asian Social Science, vol. 6, no. 8, pp. 54-63.

[4] Amorim, J, Rego, I, De Siqueira, J and Martinez-Saez, A 2011, 'Defining the design parameters of a teacher training course on the incorporation of ICT into teaching practices', Online Submission,

[5] Amory, A 2001, 'Building an Educational Adventure GameTheory, Design and Lessons', Journal of Interactive Learning Research, vol. 12 no. 2/3, pp. 249-263.

[6] Assar, S, Amrani, R and Watson, R 2010, 'ICT and education: A critical role in human and social development', Information Technology for Development, vol. 16, no. 3, pp.151-158.

[7] Barta, J and Schaelling, D1998, 'Games we play', Teaching Children Mathematics, vol.4 no. 7, pp. 388-393.

[8] Birch, A and Irvine, V 2009, 'Preservice teachers' acceptance of ICT integration in the classroom: Applying the UTAUT model', Educational Media International, vol. 46 , no. 4 , pp. $295-315$.

[9] Bonk, CJ and Dennen, VP 2005, Massive Multiplayer online gaming: a research framework for military training and education. Wisconsin Press: Madison.

[10] Bonnah, N and Unwin, T 2010, 'The contribution of ICTs to the delivery of special educational needs in Ghana: Practices and potential', Information Technology for Development, vol. 16, no. 3, pp. 191-211.

[11] Chiong, R 2010, 'Programming with games. Special Issue on Game-based Learning', Learning Technology Publication of IEEE Computer Society, vol. 12 no. 1.

[12] Deaney, R, Ruthven, K and Hennessy, S 2011, 'Teachers' developing 'practical theories' of the contribution of information and communication technologies to subject teaching and learning: An analysis of cases from English secondary schools', British Educational Research Journal, vol. 32 no. 3 , pp. $459-480$.

[13] Demıralay, R and Karadenız, Ş 2010, 'The effect of use of information and communication technologies on elementary student teachers' perceived information literacy selfefficacy', Educational Sciences: Theory and Practice, vol. 10 no. 2 , pp. $841-851$

[14] Elwood, J and MacLean, G 2009, 'ICT usage and student perceptions in Cambodia and Japan', International Journal of Emerging Technologies and Society, vol. 7 no. 2, pp. 65-82.

[15] Erdoğan, M, Kurşun, E, Şışman, G, Saltan, F, Gök, A and Yildiz, I 2010, 'A qualitative study on classroom management and classroom discipline problems, reasons, and solutions: A case of information technologies class', Educational Sciences: Theory and Practice, vol. 10 no. 2, pp. 881-891.

[16] Ghafar, M, Hamdan, A., Sihes, A. J and Harun, A 2011, 'Integrated curriculum concepts in Malaysia: Knowledge and application differentiation', European Journal of Social Science, vol. 19 no. 2, pp. 208-217.
[17] Goos, M, Brown, R and Makar, K 2008, Navigating currents and charting directions. Proceedings of the annual conference of the mathematics education research group of Australasia. 31st, Brisbane, Queensland, Australia, June 28July 1, 2008.

[18] Granič, A, Čukušič, M and Walker, R 2009, 'Learning in a Europe-wide network of schools', Educational Media International, vol. 46 no. 3, pp. 167-184.

[19] Hsu, S 2010 'Developing a scale for teacher integration of information and communication technology in grades 1-9', Journal of Computer Assisted Learning, vol. 26 no. 3, pp. 175-189.

[20] Jumani, N and Rehman, F 2011, 'Educational technology landscape - A Pakistani scene', International Journal of Academic Research, vol. 3 no. 3, pp. 757-765.

[21] Kaffash, H, Kargiban, Z, Kargiban, S and Ramezani, M 2010, A close look in to role of ICT in education, Online Submission.

[22] Kafyulilo, A 2010, Practical use of ICT in science and mathematics teachers' training at

[23] Dar es Salaam University College of education: An analysis of prospective teachers' technological pedagogical content knowledge, Online Submission.

[24] Kan, S 2011, 'Cooperative learning environment with the web 2.0 tool e-portfolios', European Journal of Social Science, vol. 21 no. 1, pp. 17-27.

[25] Karal, H Aydin, Y and Ursavaş, Ö 2009, 'Struggles for integration of the technologies into learning environment in turkey', International Journal of Social Sciences, vol. 4 no. 2, pp. 102-111.

[26] Katyal, K 2010, 'Educating teachers in Hong Kong for leadership in the age of the internet: A re-conceptualisation', Asia-Pacific Journal of Teacher Education, vol. 38 no. 4, pp. 273-284.

[27] Kazu, I 2011, 'An investigation of factors affecting the use of educational technology in Turkish primary schools', Education, vol. 131 no. 3, pp. 510-524.

[28] Kirkwood, A and Price, L 2008, 'Assessment and student learning: A fundamental relationship and the role of information and communication technologies', Open Learning, vol. 23 no. 1, pp. 5-16.

[29] Law, N, Lee, M and Chan, A 2010, 'Policy impacts on pedagogical practice and ICT use: An exploration of the results from SITES 2006', Journal of Computer Assisted Learning, vol. 26 no. 6, pp. 465-477.

[30] Leach, J 2008, 'Do new information and communications technologies have a role to play in the achievement of education for all?' British Educational Research Journal, vol. 34 no. 6 , pp. $783-805$.

[31] Luck, L and Peng, C2010, Maximizing the usage of technology-enhanced teaching and learning of science and mathematics in English program in the Malaysian secondary schools system, Online Submission.

[32] Malone, T2009, 'Toward a theory of intrinsically motivating instruction', Cognitive Science, vol. 5, pp. 333-369. 
[33] Maria, K, Persa, F, Ilias, A and Efstathios, S2011, 'Teaching art using technology: The views of high school students in Greece', Review of European Studies, vol. 13 no. 2, pp. 98109.

[34] Desmond, M., \& Lopez Turley, R. J. (2009). The role of familism in explaining the Hispanic White college application gap. Social Problems, 56, 311-334. doi: 10.1525/ sp.2009.56.2.311.

[35] Fuligni, A., \& Pedersen, S. (2002). Family obligation and the transition to young adulthood.Developmental Psychology, 38, 856-868. doi: 10.1037/0012-1649.38.5.856.

[36] Hardy, D. E., \& Katsina, S. G. (2007). Classifying community colleges: How rural community colleges fit. New Directions for Community Colleges, 137, 5-19. doi: 10.1002/cc.265.

[37] Miller, M. J., \& Brown, S. D. (2005). Counseling for career choice: Implications for improving interventions and working with diverse populations. In S. D. Brown \& R. W. Lent (Eds.), Career development and counseling: Putting theory and research to work (pp. 441- 465).Hoboken, NJ: John Wiley.

[38] Kurlaender, M. (2006). Choosing community college: Factors affecting Latino college choice. In C. L. Horn, S. M. Flores, and G. Orfield (Eds.), Latino educational opportunity. New Directions for CCs, no. 133. San Francisco: Jossey-Bass.
[39] Perez, P. A., \& Ceja, M. (2010). Building a Latina/o student transfer culture: Best practices and outcomes in transfer to universities. Journal of Hispanic Higher Education, 9, 6-21. doi: $10.1177 / 1538192709350073$

[40] Risco, C. M., \& Duffy, R. D. (2011). A career decisionmaking profile of Latina/o incoming college students. Journal of Career Development, 38, 237-255. doi: 10.1177/ 0894845310365852

[41] Phinney, J. S., Dennis, J. M., \& Gutierrez, D. M. (2005). College orientation profiles of Latino students from low socioeconomic backgrounds: A Cluster Analytic Approach. Hispanic Journal of Behavioral Sciences, 27, 387-408. doi: 10.1177/0739986305280692.

\section{Biography}

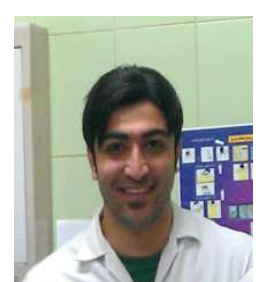

Morteza Alibakhshi-kenari was born in February 1989 at Iran, Mazandaran, Babolsar. He received the B.S. degrees from the Sari University of Medical Sciences and Health Services at Iran, in February 2011, and he is now a Ph.D student at the martyr Beheshti University of Medical Sciences and Health Services, Tehran, Iran. He is currently working in the field of Evidence Base Nursing. 